\title{
TECHNO-ECONOMIC ANALYSIS OF 1 MWE SOLAR POWER PLANT USING COMBINED RANKINE CYCLE IN IZMIR, TURKEY
}

\author{
Alain C. BIBOUM ${ }^{1, *}$, Ahmet YILANCI ${ }^{2}$ \\ ${ }^{1}$ Graduate School of Natural and Applied Sciences, Ege University, Izmir, Turkey \\ ${ }^{2}$ Institute of Solar Energy, Ege University, Izmir, Turkey \\ **Corresponding author; e-mail: biboumalain@gmail.com
}

\begin{abstract}
In the last decades, there is an increasing attention on renewable energy sources to overcome energy related problems such as global warming/climate change, security of energy supply, depletion of fossil fuels, unpredictable energy prices, conflictions on energy sources etc. Solar energy is an abundant source of renewable energy readily available on the earth. With the recent developments in solar energy conversion technologies, concentrating solar power (CSP) systems for heat and power productions have become attractive solutions. Currently, CSP systems using parabolic trough collectors (PTCs) are dominated the global CSP market since there are the most mature technology and the most installed CSP systems in the world. Turkey is one of the countries benefiting from good solar radiation, so CSP systems may be one of the solutions for the renewable energy production. In this study, technoeconomic analysis of a small (1 MWe) PTC-CSP power plant using combined Rankine cycle for electricity production in Izmir, Turkey, is presented as a case study for an example of PTC-CSP power plant utilization in the locations in Turkey with high solar radiation values. Levelized cost of electricity (LCOE), internal rate return, net present value and payback period of the power plant for three different layout configurations of the PTCs in the solar field are calculated by using System Advisory Model (SAM), MATLAB and Excel softwares. The results show that for $1 M W$ P PTC-CSP power plant in Izmir, the initial investment cost is approximately 3.9 Million USD with LCOE of 135 USD/MWh, and the annual operational cost of 37.5 USD/MWh with a payback period of 11.5 years. Also, the required cost for site optimization (RCO) per $k W_{\text {th }}$ of exergy destruction and energy loss for the solar field configuration \#1 is found to be 1830.2 USD and 1887.5 USD respectively. These results figure out that there are some possible improvements to be achieved. However, the values for the solar field configuration \#2 and \#3 are closed to the minimal $R C O$ per $k W_{\text {th }}$. This means that no further improvement can be achieved.
\end{abstract}

Key words: Solar energy, Concentrating Solar Power, Parabolic Trough Collectors, Techno-economic analysis, Exergy, Combined Rankine cycles. 


\section{Nomenclature}

$\boldsymbol{A}_{\boldsymbol{a p}}$
$C_{\text {net }}$
$c_{p}$
$E$
$F^{\prime}$
$h$
$\dot{m}$
$N_{\text {loop }}$
$\dot{Q}_{\text {abs }}$
$\dot{Q}_{\text {solar }}$
$\dot{Q}_{\text {use,in }}$
$O_{\text {net }}$
$S$
$T$
$T_{o}$
$T_{\text {sun }}$
$U_{L}$
$U_{o}$

Greek symbols

$\eta$

$\eta_{e x}$

$\eta_{o}$

$\eta_{t h}$

$\pi$

$\psi$

\section{Subscripts}

eva

con

Th

sf

in

out

Acronyms

AOE

CER/TAX

$\mathrm{CR}$

CSP

DNI

EAIT

EBIT

EPC

FiT

$\mathrm{HTF}$

ICC

IHE

IRR
Aperture area $\left(\mathrm{m}^{2}\right)$

Net installed capacity (MW)

Specific heat $(\mathrm{kJ} / \mathrm{kgK})$

Energy $(\mathrm{kW})$

Collector efficiency factor (-)

Specific enthalpy $(\mathrm{kJ} / \mathrm{kg})$

Mass flow rate $(\mathrm{kg} / \mathrm{s})$

Number of loop (-)

Useful energy output $\left(\mathrm{kW}_{\text {th }}\right)$

Solar power input $\left(\mathrm{kW}_{\text {th }}\right)$

Absorbed energy input $\left(\mathrm{kW}_{\text {th }}\right)$

Net energy generation (MWh)

Specific entropy $(\mathrm{kJ} / \mathrm{kgK})$

Temperature (K)

Dead state temperature $(\mathrm{K})$

Apparent sun temperature $(\mathrm{K})$

Heat loss coefficient $\left(\mathrm{W} / \mathrm{m}^{2} \mathrm{~K}\right)$

Overall heat transfer coefficient $\left(\mathrm{W} / \mathrm{m}^{2} \mathrm{~K}\right)$

Collector energy efficiency (-)

Exergy efficiency (-)

Optical efficiency (-)

Energy efficiency (-)

Heat exchanger effectiveness (-)

Exergy $(\mathrm{kW})$

Evaporator

Condenser

Therminol VP-1

Solar field

Inlet

Outlet

Annual Operating Expenses

Certified Tax Carbon

Central Receiver

Concentrating Solar Power

Direct Normal Irradiation

Earning after Interest and Tax

Earnings before Interest and Tax

Engineering Procurement and Construction

Feed in Tariff

Heat Transfer Fluid

Capital Cost

Intermediate Heat Exchanger

Internal Rate Return 


ISG/DSG
IT
LCOE
LFR
MENA
NPV
O\&M
ORC
PBP
PD
PTC
RCO
SAM
STPP
SRC
TDC
TES
TIC

\author{
Indirect/Direct Steam Generation \\ Initial Investment \\ Levelized Cost of Electricity \\ Linear Fresnel Reflectors \\ Middle East North Africa \\ Net Present Value \\ Operations and Maintenance \\ Organic Rankine Cycle \\ Payback Period \\ Parabolic Dish \\ Parabolic Trough Collector \\ Required Cost for the Optimization \\ System Advisor Model \\ Solar Thermal Power Plant \\ Steam Rankine Cycle \\ Total Direct Cost \\ Thermal Energy Storage \\ Total Installed Cost
}

\section{Introduction}

Solar energy is the most abundant source of renewable energy which is readily available in earth. It is basically used as a heat source to produce thermal energy at desired temperature range (typically up to $1200^{\circ} \mathrm{C}$ ) for different utilization purposes in various ways/technologies. Concentrating solar power (CSP) systems such as parabolic trough solar collectors (PTCs), solar towers (ST), and solar dishes, linear Fresnel reflectors, can be used to produce thermal energy at high temperatures (from $150^{\circ} \mathrm{C}$ to $1200^{\circ} \mathrm{C}$ ) for heating, cooling and power demands. These systems require high solar direct normal irradiance (DNI) to obtain such temperatures. The PTCs are considered to be one of the most mature and lowest cost CSP systems [1]. Therefore, PTCs are the most widely used for the CSP plant constructions. This technology was developed in 1912 in Cairo, Egypt, and the first commercial CSP plant using PTC was installed in Grenada, 2008 named Andasol-1 [2]. PTC is one of the concentrated solar power technology containing large mirrors used to reflect the solar radiation onto a receiver. The collector field contains loop which have more than one solar collector assemblies (SCA) each and are placed in parallel rows aligned on a north-south axis. The solar field configuration tracks the sun trajectory which move from east to west throughout the day. The aim of the tracking system is to ensure that the solar radiation is continuously focused on the absorber pipes containing inside of receiver. The receiver or absorber tube has to achieve the maximum absorbed solar irradiation and reduce the heat losses in the receiver during this process in order to transfer significantly the heat to the heat transfer fluid which move through receiver. According to some parameters such as steam generation system types and thermodynamic cycle used to generate electricity, the heat transfer fluid can be water, thermal oil, such as diphenyl oxide, Therminol VP-1, Xcelterm-MK1 or molten salt and the others which are a kind of mixture with different percentages. The absorber has to be designed with a high absorption coefficient through its focal line, to ensure an efficient heating process of the working fluid. Contrary to the output heating value of the HTF which depends on the parameters like a local direct normal irradiation (DNI), absorption and emittance coefficient and others. Its output temperature value is related to a type of thermal oil used for heat transfer process. The solar-to-electric efficiency depends on the yearly amount of energy 
produced, the field layout and the annual DNI, its value is approximately $15 \%$ for the CSP system using PTC technology [3]. When the solar field system is integrated with a steamturbine power plant, the process is called direct steam generation (DSG) technology and uses water/stem as a heat transfer fluid. If the transfer fluid is not water and an intermediate heat transfer system is used to connect the solar field and the power block like in our case, the technology is called indirect steam generation (ISG) using water as a working fluid [4]. The biggest advantages of ISG system are: the heat transfer fluid such as molten salt which can be stored and used during sunlight unavailable period, the thermal energy storage (TES) system which can be built anytime to generate electricity during the night, the operation and maintenance works which can be done in short periods without a negative impact in the energy production. The major disadvantage is its initial investment and O\&M cost, which are influenced by the use of the IHE and TES system.

Silva et al. [5] did thermo-economic design optimization of a parabolic trough solar plant for industrial processes with memetic algorithms. The authors carried out a levelized cost of energy of 5 cent $€ / \mathrm{kWh}$. Mokheimer et al. [6] studied performance and cost of a solar thermal power plant using the EuroTrough solar collector (ET-100) and for Luz solar collector (LS-3). This study showed that the specific cost for a PTC field per unit aperture area and the specific cost of different mechanical works can be cut by about $46 \%$ and $48 \%$ on 10 hectares.

Khalilpour et al. [7] analyzed various designs and steam extraction design configurations of a hybridized power plant using CSP - biomass hybrid technology while using System Advisor Model (SAM) as the main software for simulation. The results showed that series design configuration had the lowest Levelized Cost of Electricity while parallel design presented the highest installed capacity. Solar energy is this most abundant source of energy which can be combined as a suitable alternative to fossil energy. It can be converted to electricity using different conversion and thermodynamic cycles. Calise et al. [8] did a dynamic simulation model of a solar-geothermal polygeneration system and its exergy and exergoeconomic analyses. The thermal power plant generally combine thermodynamic cycles to generate electricity in order to perform the plant efficiencies. They found that the levelized cost of electricity is between $0.1475-0.1722 € / \mathrm{kWh}$. Zare and Hasanzadeh [9] studied a closed Brayton cycle combined with Organic Rankine cycle for solar power tower plants in order to optimize electricity generation, in their study they found the efficiencies of the system to be $23.2 \%$. They studied a solar power plant which uses central receiver technology combined with Rankine cycle for electricity generation. The solar energy converted to electricity can be done by different processes and thermodynamic combined cycles or not. A study of a combined Rankine cycle using water and R134a as a working fluid and Therminol VP-1 as a heat transfer fluid was done by Biboum et al. [10]. In the analysis, overall energy efficiency of the system is found to be $23.2 \%$. Adibathla and Kaushick [11] attempted to integrate a solar aided system to existing $500 \mathrm{MWe}$ coal-fired thermal power plant. This study is conducted to elaborate an exergoeconomic analysis of a 500MWe studied system. The results showed that the solar field and boiler have the maximum exergy destruction ratios $78.90 \%$ and $56.52 \%$ respectively. Ahmadzadeh et al. [12] studied thermodynamic performance and thermoeconomic analysis of the proposed system, in order to develop a genetic algorithm optimization. This algorithm is conducted to $25 \%$ improvement in thermal energy, $21.3 \%$ in exergy efficiency and $7.7 \%$ reduction in total cost of the proposed system, PTC has been shown as the best technology among CSP Technologies for main criteria related to commercial electricity generation based on site characteristic and adopted configuration. Bishoyi and Sudhakar [13] studied a configuration of 100 MWe solar thermal power plant using 16 modules of linear Fresnel technology per SCA able to generate 264 GWh per year. 
LCOE is one of the main values of the economic analysis. A recent study presented by Bonyadi et al. [14] studied solar-geothermal power plant based on the hybridization of an existing geothermal and a solar-powered steam-Rankine. In the study, they used Meteonorm Software to collect DNI meteorological data. The results show that a levelized cost of energy (LCOE) for each configuration is in the range of 163-172 USD/MWh.

The purpose of this study is to highlight the cost of the optimization work per $\mathrm{kW}$ capacity for 1 MWe solar plant. This consists of taking into account the cost of the site improvement in order to reduce the energy losses and exergy destruction, which may be due to various factors such as the transport of heat and working fluids, the quality of equipment and others. This work establishes the relationship existing between the site configuration and the necessary cost for its optimization; comparison of the expenditure due to the optimization work of the solar field according to the type of configuration. The two points mentioned show the particular aspect of the work that is generally carried out and implemented for large and medium-sized plants and justifies its limits for small installations.

\section{Description of the System}

Schematic view of the proposed system is shown in Figure 1. The annual thermal energy and electricity needs of the industry have been assessed to cover them as a priority. The system containing the solar field consisting of parabolic trough collectors (PTCs), the intermediate heat exchanger, the piping system, the combined Rankine cycles as a power block and the other auxiliary equipment such as pumps, recuperator, valves, mixing tank, water tank etc. In the study, PTC-CSP system is designed without thermal storage. In this system, solar radiation is concentrated by parabolic through collectors in the solar field to produce high temperatures. Therminol VP-1 used as a heat transfer fluid is transported to the solar field circuit for transferring the thermal energy while water and the R134a as the working fluids circulate in the high pressure and low pressure (power block) circuit. A pump circulates Therminol VP-1 with a certain mass flow rate to maintain the temperature as $391{ }^{\circ} \mathrm{C}$ at the outlet of the solar field. Thermal energy from the solar field to the power block is transferred by an intermediate heat exchanger to produce water vapor for Steam Rankine Cycle (SRC). The water from the tank is sent under pressure, it first passes through to the heat recovery to increase its temperature before entering the intermediate heat exchanger. The saturated steam is immediately transmitted to the turbine to generate electricity, while the non-saturated steam from the turbine is used to feed the recuperator and the low-pressure power circuit (Organic Rankine Cycle - ORC). Thus, electricity generation is obtained based on combined steam Rankine cycle (SRC) and organic Rankine cycle (ORC). ORC can be defined as a recovery system to perform electricity generation of the solar power plant. Generally, an important portion of wasted heat can be used for power generation using ORC [9]. Usually, there are two arrangement types in CSP plant using parabolic trough collectors, I and $\mathrm{H}$. This study also shows which configuration can provide a better-required cost for optimization to perform plant capacity through an acceptable expenditure for exergy destruction and energy loss recovery as possible. 


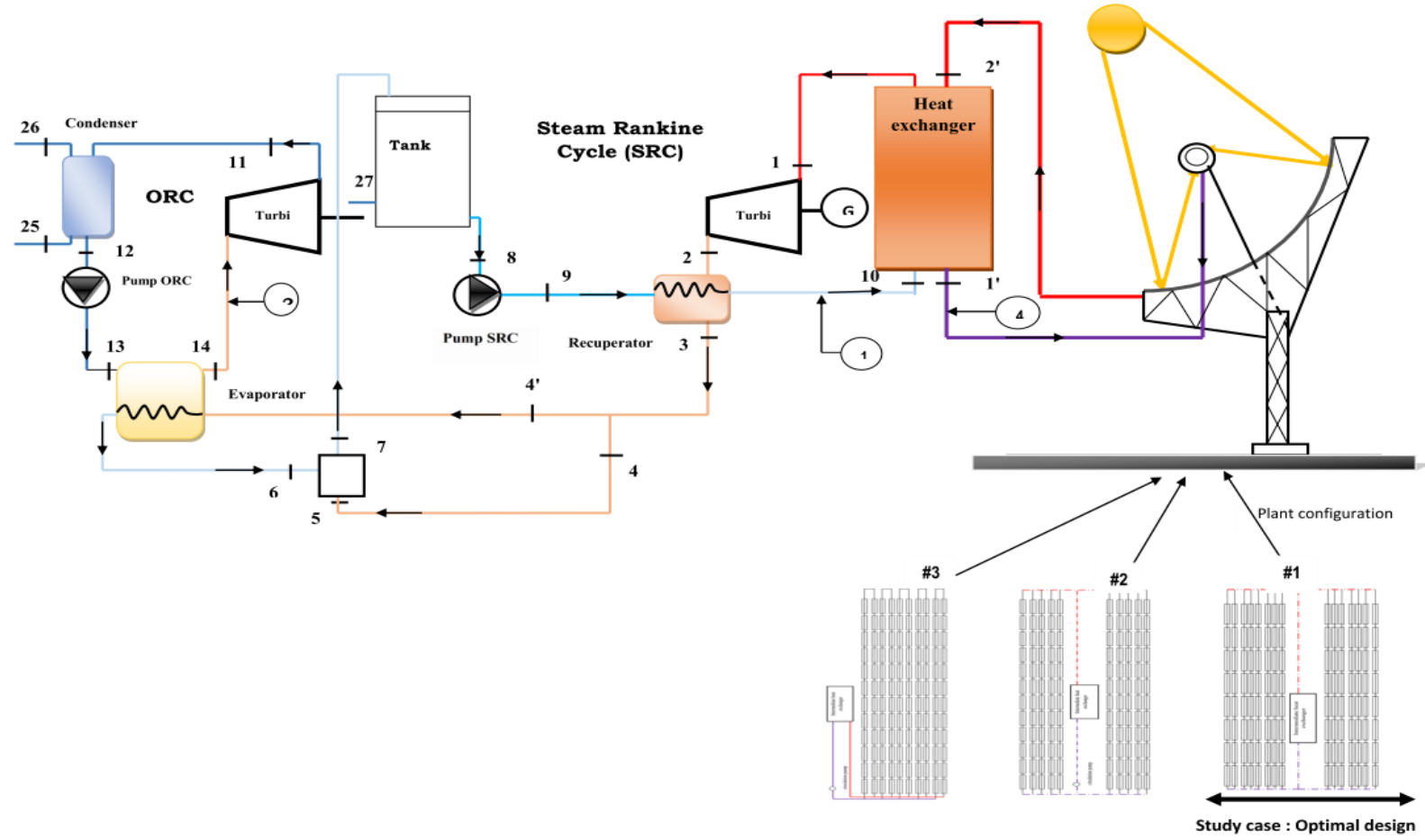

Figure 1. Schematic view of 1 MWe solar power plant containing three different solar field configurations (\#1 and \#2 are $H$ type and \#3 is I type)

The monthly average DNI value in the study area is estimated at $523.7 \mathrm{~W} / \mathrm{m}^{2}$, and the other meteorological data are avaliable in Table 1 . The annual energy production can be performed using the meteorological data for Izmir, Turkey $\left(38.25^{\circ} \mathrm{N}\right.$ latitude and $27.14^{\circ} \mathrm{E}$ longitude) extracted from a TMY3 format file provided by Meteonorm Software.

Table 1. Meteorological data of Izmir [15]

\begin{tabular}{|lccccc|}
\hline Months & $\begin{array}{c}\text { Monthly global } \\
\text { solar } \\
\text { radiation }\left(\mathbf{k W . h} / \mathbf{m}^{\mathbf{2}}\right)\end{array}$ & $\begin{array}{c}\text { Av. solar } \\
\text { Daily sunshine } \\
\text { duration (h/day) }\end{array}$ & $\begin{array}{c}\text { Aadiation during } \\
\text { sunshine hours } \\
\left(\mathbf{W} / \mathbf{m}^{2}\right)\end{array}$ & $\begin{array}{c}\text { Ambient } \\
\text { temperature } \\
\left({ }^{\mathbf{0}} \mathbf{C}\right)\end{array}$ & $\begin{array}{c}\text { Wind speed } \\
(\mathbf{m} / \mathbf{s})\end{array}$ \\
\hline January & 65 & 4.1 & 395.5 & 6.8 & 2.7 \\
February & 74 & 4.8 & 403.2 & 8.1 & 3.2 \\
March & 124 & 6 & 453.6 & 11.9 & 3.2 \\
April & 163 & 7.8 & 473.7 & 15.8 & 2.7 \\
May & 204 & 9.7 & 544.3 & 21.2 & 2.7 \\
June & 222 & 11.2 & 726.8 & 26.4 & 3.4 \\
July & 236 & 12 & 751.5 & 28.4 & 3.8 \\
August & 211 & 11.3 & 685.1 & 27.7 & 3.5 \\
September & 163 & 9.1 & 605 & 22.5 & 2.8 \\
October & 116 & 7.0 & 513.3 & 18.0 & 2.5 \\
November & 75 & 5.3 & 394.7 & 12.5 & 2.3 \\
December & 55 & 4.2 & 333.7 & 8.2 & 2.6 \\
\hline Av. values & $\mathbf{5 . 7 8}$ & $\mathbf{7 . 0 8}$ & $\mathbf{5 2 3 . 7}$ & $\mathbf{1 7 . 3}$ & $\mathbf{3 . 0}$ \\
\hline
\end{tabular}




\section{Technical and Economic Analysis}

\subsection{Energy and Exergy Analyses}

For a control volume at steady state, the energy and exergy balance equations are expressed as below.

$\dot{E}_{\text {in }}=\dot{E}_{\text {out }}$

$\dot{\psi}_{\text {in }}-\dot{\psi}_{\text {out }}=\dot{\psi}_{D}$

where $\dot{E}_{\text {in }}$ and $\dot{E}_{\text {out }}$ are the total energy rates entering and exiting to the control volume respectively; $\dot{\psi}_{\text {out }}$ and $\dot{\psi}_{\text {int }}$ are the total exergy rates entering and exiting to the control volume respectively, while $\dot{\psi}_{D}$ is the exergy destruction rate within the component. The exergy rate of a fluid can be obtained from the following equation:

$\dot{\psi}=\dot{m}\left[\left(h-h_{o}\right)-T_{o}\left(s-s_{o}\right)\right]$

For each subsystem, thermodynamic models are developed based on the equations above, and each subsystem are analyzed thermodynamically by using MATLAB program.

\subsubsection{Solar field}

The arrangement of solar field consists of solar collectors so as to create a SCA, and SCAs have a tracking system to follow the sun. In this study, Therminol VP-1 is used as heat transfer fluid at the outlet temperature of $391^{\circ} \mathrm{C}$. The energy received by solar field system can be written as follow using the equation given by Shahin et al. [17]:

$\dot{Q}_{\text {input }}=D N I . A_{a p}$

Petela's equation [18] can be used to determine the exergy rate from solar radiation:

$\dot{E}_{x, s f}=D N I \cdot A_{a p} \cdot\left(1+\frac{1}{3}\left(\frac{T_{o}}{T_{\text {sun }}}\right)^{4}-\frac{4}{3}\left(\frac{T_{o}}{T_{\text {sun }}}\right)\right)$

where $A_{a p}$ is the aperture area of the solar field recovered by parabolic mirror; DNI is direct normal irradiation which is the irradiation value received on the solar field aperture; $T_{o}$ and $T_{\text {sun }}(5739 \mathrm{~K})$ are dead state temperature in the location and apparent sun temperature as an equivalent heat source temperature [18]. The parameters such as the area of PTCs, the number of loops, the mass flow rate of the HTF, type of absorber, turbine size and HTF pipe and many others specifications presented in Table 1 are taken from SAM software.

Thermodynamic analysis via Matlab software is done to determine the mass flow rate of HTF which affects considerably the value of heat transferred to SRC. The value of the useful energy, the exergy and the exergy destruction are given by:

$$
\begin{aligned}
& \dot{Q}_{u}=\dot{m}_{T h} \cdot C_{P, T h} \cdot\left(T_{T h, \text { out }}-T_{T h, \text { in }}\right) \\
& \dot{E}_{x, S f_{-} u s e}=\dot{m}_{T h \cdot} .\left[\left(h_{T h, \text { out }}-h_{T h, \text { in }}\right)-T_{o}\left(s_{T h, \text { out }}-s_{T h, \text { in }}\right)\right]
\end{aligned}
$$


$\dot{E}_{x, D, s f \_u s e}=N_{\text {loop }} \cdot \dot{m}_{T h} \cdot\left[C_{P, T h} \cdot\left(T_{T h, o u t}-T_{T h, \text { in }}\right)-\left(h_{T h, o u t}-h_{T h, \text { in }}\right)+T_{o}\left(s_{T h, \text { out }}-s_{T h, \text { in }}\right)\right]$

The exergy efficiency of solar field is given by: $\eta_{e x_{-} f f}=\frac{\dot{Q}_{u}}{\dot{E}_{x, s f}}$

\subsubsection{Steam (SRC) and Organic Rankine cycles (SRC) (Power block)}

As described in Figure 1, SRC contains a steam turbine which produces electricity. The mass flow rate of water can be changed according to operating conditions closely related to meteorological data. Energy analysis and exergy balance of SRC can be found using these equations as follow:

$\dot{W}_{\text {net_Solar_SRC }}=\dot{m}_{w} \cdot\left(h_{1}-h_{2}\right)-\dot{m}_{w}\left(h_{9}-h_{8}\right)$

ORC's working fluid used to recover low temperature of SRC's wasted heat in this study is R134a.Thermodynamic analysis of ORC can be written as follow:

$\dot{Q}_{e v a}=\dot{m}_{w 1}\left(h_{4^{\prime}}-h_{6}\right)$

$\dot{E}_{x_{-} e v a}=\left(\dot{\psi}_{14}-\dot{\psi}_{13}\right)$

$\dot{Q}_{\text {cond,orc }}=\dot{m}_{R 134 a}\left(h_{12}-h_{11}\right)$

$\dot{W}_{\text {net_ORC }}=\dot{m}_{R 134 a} \cdot\left(\left(h_{14}-h_{11}\right)-\left(h_{13}-h_{12}\right)\right)$

Exergy destruction can be obtained from this equation:

$$
\begin{aligned}
& \dot{\psi}_{D, E v a}=\left(\dot{\psi}_{14}-\dot{\psi}_{13}\right)-\left(\dot{\psi}_{4^{\prime}}-\dot{\psi}_{6}\right) \\
& \dot{\psi}_{D, \text { Cond }}=\left(\dot{\psi}_{11}-\dot{\psi}_{12}\right)-\left(\dot{\psi}_{26}-\dot{\psi}_{25}\right) \\
& \dot{E}_{x, D_{-} O R C}=\dot{E}_{x, \text { eva }}-\dot{E}_{x_{\text {, work_ORC }}}
\end{aligned}
$$

Main equations and assumptions to find out the overall performance parameters of the power plant is presented in Table 2 . 
Table 2. Equations and assumptions for the performance analysis

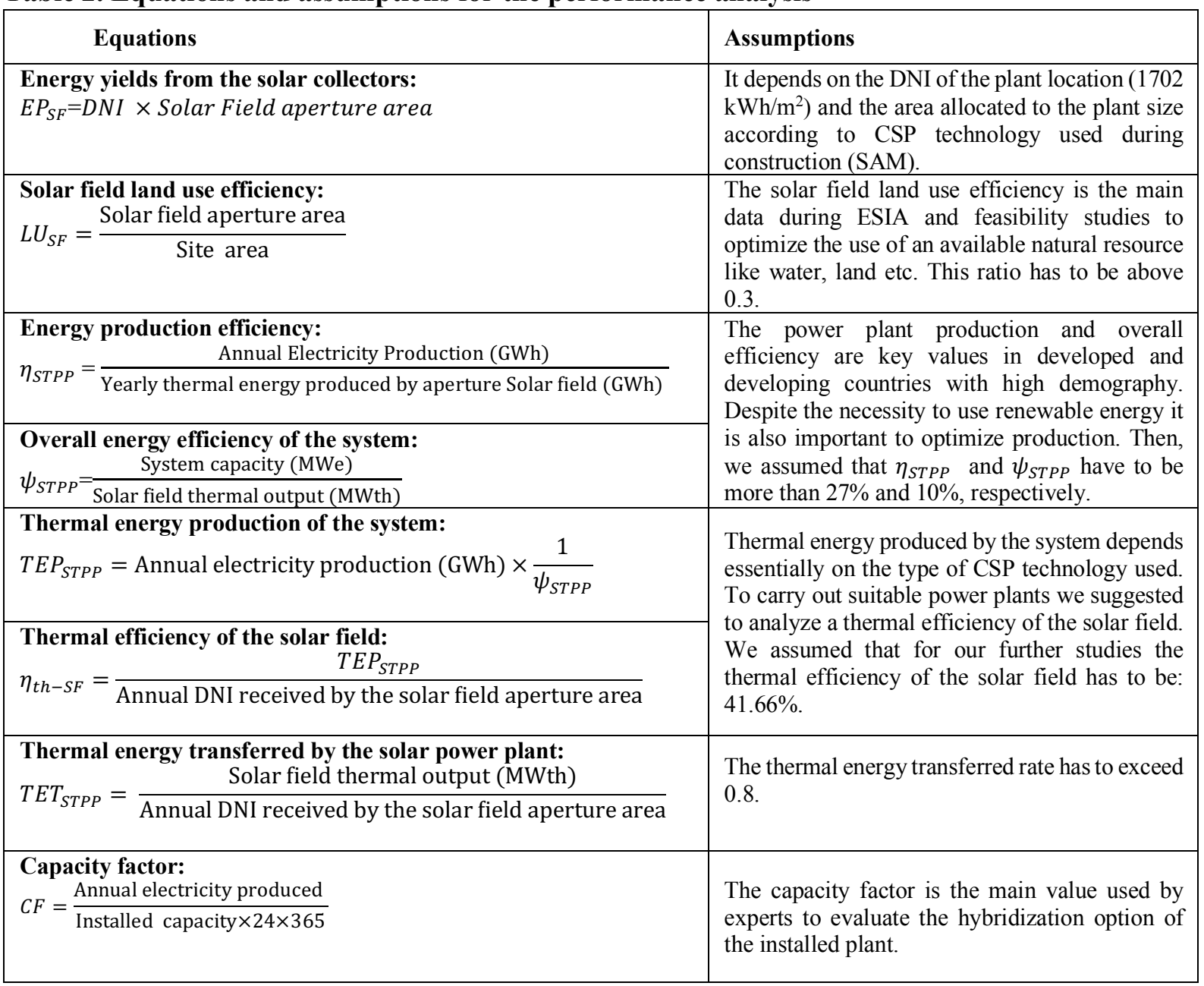

\subsection{Economic Analysis}

The aim of a techno-economic analysis is to find the total system costs through thermodynamic and economic analyses of a system together. It is important for the optimization of PTC-CSP plants both technically and economically. In this section, economic analysis based on financial parameters are explained briefly.

The net earnings of the consecutive years are discounted to year zero with the rate selected to satisfy Marginal Average Rate of Return. The investment is deducted from the present sum of benefits. The NPV is written as:

$N P V=-S+\sum_{j=1}^{i} \frac{C F_{i}}{(1+r)_{i}}$

Internal Rate of Return (IRR) discounts all the cash back, thereby giving zero NPV during the investment life of a project, is expressed as:

$$
-S+\sum_{j=1}^{i} \frac{C F_{i}}{(1+r)_{i}}=0
$$


A set of projects that can earn maximum benefits can be easily selected by the management when the IRR is superior to the discount rate, $r$.

The payback period (PBP) can be defined as a number of years that the project takes to recover its total investment by the earnings after interest and tax (EAIT) deducted, it can be written as follow:

$P B P=\frac{T I}{E A I T}$

For the economic analysis, Feed-in-Tariff (FiT) prices for solar thermal power plants provided by the government in Turkey are listed in Table 3. The base rate is $13.3 \mathrm{USD} / \mathrm{kWh}$ for the solar thermal power plant. A specific bonus tariff for the domestic contribution is also provided for specific technologies and environmental considerations. Radiation collection tubes, sun tracking systems and the use of mechanical accessories for the steam generation systems increase the FiT prices with 2.4 USDcent/kWh, 0.6 USDcent/kWh and 2.4 USDcent/kWh respectively.

Table 3. Feed in tariff prices for concentrating solar power generation technologies in Turkey

\begin{tabular}{|l|c|}
\hline \multicolumn{1}{|c|}{ Concentrating Solar Power Generation Technologies } & $\begin{array}{c}\text { Domestic Contribution } \\
\text { (USDcent/kWh) }\end{array}$ \\
\hline 1- Radiation collection tube & 2.4 \\
2- Reflective surface plate & 0.6 \\
3- Sun tracking system & 0.6 \\
4- Mechanical accessories of the heat energy storage system & 1.3 \\
5- Mechanical accessories of the steam production system for the solar tower & 2.4 \\
6- Stirling engine & 1.3 \\
7- Structural mechanics & 0.6 \\
Production facility based on renewable energy & Feed-in-tariff Prices \\
Solar power system & (USDcent/kWh) \\
\hline
\end{tabular}

\section{Results and Discussion}

The main characteristics of the system at design conditions are summarized in Table 4. In this study, commercial available PTCs (Luz-S2 and PTR Schott technologies) are used since they are able to provide heat around $500^{\circ} \mathrm{C}$ depending on different criteria such as site assessment and configuration, heat transfer fluid (HTF), thermal properties of the raw materials of the collectors and receivers.

In the study, the following assumptions have been considered:

- The electricity need is $975 \mathrm{MWh}$ annually with an average at $95 \mathrm{MWh}$ per month.

- The system is operating in steady state conditions.

- Pressure drops in all the heat exchangers and the pipes are neglected.

- Heat losses from the components (excluding PTSC) are neglected.

- Thermal oil is considered as an incompressible fluid.

- The kinetic and potential energies and exergies are neglected, due to absence of chemical reactions in the considered system and also in heat transfer fluid. (Chemical exergy can 
be also cancelled).

- Turbine and pump used in Rankine cycle have isentropic efficiencies of 0.8 ,

- Energy efficiency for the recuperator is equal to 0.91 ,

Table 5 presents the total direct cost (TDC) containing the solar field cost and the power block cost; the total indirect cost including land cost and engineering procurement and construction (EPC) work cost, and the total installed cost (TIC). A power block has a high operation and maintenance expenditure cost because of its main components such as exchangers, turbine, and condenser. Prices of other units are relatively low as mentioned in Table 5.

Table 4. Design parameters of PTC-CSP plant for configuration \#3 [16]

\begin{tabular}{|l|l|c|}
\hline Sub-system & \multicolumn{1}{|c|}{ Parameter } & Value \\
\hline Solar Field & Aperture /active area & $17800 \mathrm{~m}^{2} / 7285 \mathrm{~m}^{2}$ \\
& Average irradiation & $523.7 \mathrm{~W} / \mathrm{m}^{2}$ \\
& Heat transfer fluid & Therminol VP-1 \\
& Loop outlet temp. & $391 .{ }^{\circ} \mathrm{C}$ \\
& Number of module per SCA & 12 \\
& Number of loops & 7 \\
& Configuration type & I type (Figure 1$)$ \\
& Collector & Luz LS-2 \\
& Receiver & Schott PTR80 \\
\hline Power block & Capacity & $1 \mathrm{MWe}$ \\
& Efficiency & 0.336 \\
& Outlet temp. & $391{ }^{\circ} \mathrm{C}$ \\
& HTF mass flow rate & $12.4 \mathrm{~kg} / \mathrm{s}$ \\
\hline Parasitic & Parasitic loss ratio & 0.02273 \\
& Other parasitic losses & - \\
\hline
\end{tabular}

Table 5 presents the installation and system costs of the $1 \mathrm{MW}_{\mathrm{e}}$ Concentrated solar power plant. The operation and maintenance (O\&M) costs are divided between variable cost and fixed cost of the studied plant. Annual O\&M cost is estimated as 23USD/MWh in the case of annual energy generated or $25 \mathrm{USD} / \mathrm{kW}$-yr if the total installed cost of solar power plant is considered. The contingency of solar power plant construction is estimated at $6 \%$ of the total direct cost (TDC). The total area of the plant is $17.800 \mathrm{~m}^{2}$ and the estimated installed cost per $\mathrm{kW}$ is 3875.25 USD. Solar power plant technologies vary widely with DNI availability and conversion processes. Likely with a direct combustion-based plant, a solar thermal plant using ISG system run a steam turbine and can store a part of thermal energy produced during the day. Thus, the investment cost varies substantially with technology, operating conditions and the used working fluid and heat transfer fluid. The working fluid and a HTF are an important factor in solar power generation. The fluids characteristics can affect the plant efficiencies. Another important factor is the system cost (constructions, parabolic trough collectors, piping system and power block) because their price are directly related to thermal properties, such as inlet/outlet temperatures of different fluids. 
Table 5. Economic parameters of PTC-CSP plant for configuration \#3 [16]

\begin{tabular}{|l|l|c|}
\hline \multicolumn{1}{|c|}{ System cost } & \multicolumn{1}{|c|}{ Unit } & Values \\
\hline Site improvement & $\mathrm{USD} / \mathrm{m}^{2}$ & 15 \\
Solar field & $\mathrm{USD} / \mathrm{m}^{2}$ & 80 \\
HTF system & $\mathrm{USD} / \mathrm{m}^{2}$ & 40 \\
Power plant & $\mathrm{USD} / \mathrm{kWe}$ & 750 \\
Balance of plant & $\mathrm{USD} / \mathrm{kWe}$ & 60 \\
Contingency & - & 0.06 \\
\hline Total direct cost & $\mathrm{USD}$ & 3111566.50 \\
Total indirect cost & $\mathrm{USD}$ & 613799.81 \\
Total cost & $\mathrm{USD}$ & 3725366.25 \\
Total cost per kW & $\mathrm{USD} / \mathrm{kW}$ & 3725.25 \\
\hline Fixed O\&M cost by capacity & USD/kW-yr & 25 \\
Variable O\&M cost by generation & USD/MWh & 2.3 \\
\hline
\end{tabular}

Table 6 shows the main technical parameters considered for techno-economic analysis of the solar power plant in Izmir, Turkey.

Table 6. Technical parameters of solar thermal power plant.

\begin{tabular}{|l|l|l|l|}
\hline Capacity $\left(\mathrm{MW}_{\mathrm{e}}\right)$ & 0.9 & Design gross output & $1 \mathrm{MW}_{\mathrm{e}}$ \\
\hline Yearly DNI $\left(\mathrm{kWh} / \mathrm{m}^{2}\right)$ & 1702 & $\begin{array}{l}\text { Total annual DNI received by the land and } \\
\text { solar field aperture area }(\mathrm{GWh})\end{array}$ & $\begin{array}{l}30.3 \\
12.4\end{array}$ \\
\hline Thermal output of the solar field $\left(\mathrm{MW}_{\mathrm{t}}\right)$ & 2.81 & Yearly electricity production $\left(\mathrm{GWh}_{\mathrm{e}}\right)$ & $1.622 \mathrm{GWh}_{\mathrm{ei}}$ \\
\hline Power plant production efficiency $(\%)$ & 13.1 & Power block rated conversion $(\%)$ & 35.6 \\
\hline Annual water usage $\left(\mathrm{m}^{3}\right)$ - (times per year) & $667(52)$ & Capacity factor $(\%)$ & 20.6 \\
\hline
\end{tabular}

Thermodynamic analysis of the system (energy and exergy analyses) has been done in order to show the performance of the power plant. The solar power plant is divided into two subsystems namely, solar field and power block (Steam and Organic Rankine Cycle). These subsystems are considered as one block containing many components studied individually using MATLAB program for simulation. Results of the analysis for the optimized solar field configuration \#3 are given in Table 7. Exergy destruction and energy loss are $2101.3 \mathrm{~kW}_{\text {th }}$ and $2052.8 \mathrm{~kW}_{\text {th }}$ respectively. The exergy destruction values of the system components are shown in Table 7. Table 7 shows that maximum exergy destruction occurs in the solar field. The fans and pumps impose a load to operate themselves. The developed power plant model handles also the parasitic loads. These parasitic loads are estimated as a percent of gross capacity for the calculation of net generating capacity (MW) and net energy output (MWh) of the solar power plant.

Table 7. Energy and exergy analyses of the CSP plant

\begin{tabular}{|l|lcccccccc|}
\hline & \multicolumn{4}{|c}{ Energy Analysis } & \multicolumn{4}{c|}{ Exergy Analysis } \\
\hline \multirow{2}{*}{ System } & \multirow{2}{*}{ Component } & $\begin{array}{c}\text { Input } \\
(\mathrm{kW})\end{array}$ & $\begin{array}{c}\text { Output } \\
(\mathrm{kW})\end{array}$ & $\begin{array}{c}\text { Losses } \\
(\mathrm{kW})\end{array}$ & $\begin{array}{c}\text { En. Eff. } \\
(-)\end{array}$ & $\begin{array}{c}\text { Input } \\
(\mathrm{kW})\end{array}$ & $\begin{array}{c}\text { Output } \\
(\mathrm{kW})\end{array}$ & $\begin{array}{c}\text { Dest. } \\
(\mathrm{kW})\end{array}$ & $\begin{array}{c}\text { Ex. Eff. } \\
(-)\end{array}$ \\
\hline \multirow{3}{*}{ Subsystem1 1} & CSP field & 3093.8 & 1899.8 & 1194 & 0.609 & 3093.8 & 1790 & 1303.6 & 0.5786 \\
& Abs. heat & 1899.8 & 1468.2 & 431.6 & 0.772 & 1790.2 & 1383 & 407.5 & 0.7724 \\
& Piping syst. & 1468.2 & 1427.8 & 40.4 & 0.972 & 1382.7 & 1237. & 145.6 & 0.8946 \\
\hline \multirow{5}{*}{ Subsystem2 2} & Power cycle & 1427.8 & 1047.9 & 379.9 & 0.706 & 1237.1 & 1005 & 231.8 & 0.7269 \\
& Low cycle & 244.3 & 19.4 & 224.9 & 0.0793 & 200.3 & 3.7 & 196.6 & 0.0186 \\
& Comb. cycle & 1427.8 & 1067.3 & 360.5 & 0.720 & 1237.1 & 1009 & 228.1 & 0.7429 \\
& Overall plant & $\mathbf{3 0 9 3 . 8}$ & $\mathbf{1 0 4 1}$ & $\mathbf{2 0 5 2 . 8}$ & $\mathbf{0 . 3 2 7}$ & $\mathbf{3 0 9 3 . 8}$ & $\mathbf{9 9 2 . 5}$ & $\mathbf{2 1 0 1 . 3}$ & $\mathbf{0 . 3 2 0 7}$ \\
\hline
\end{tabular}


The annual energy production of the plant is presented in Table 6, part of this production is intended for the energy needs of the industry estimated at 975.02MWh. The remaining electricity production estimated at 696.02 MWh is for sale with a feed-in-tariff price of 19.6 USDcents $/ \mathrm{kWh}$. The profits are related to the quality of production and the type of technology used. Furthermore, the thermal energy produced for manufacturing industrial processes are not take into account in the profit calculation. To produce electricity, the quality of production through the use of solar energy has been controlled to protect the grid stability and the sustainability of the environment by combining solar with other energy sources which cannot produce tons of $\mathrm{CO}_{2}$. Table 6 and 9 give an estimated value of the bonuses achieved for each MWh produced with the preservation of the environment (51.41 USD /MWh). The use of CSP-PTC and the Rankine Combined Cycle help to obtain a bonus on each kWh of electricity produced at approximately 5.14 USD cent $/ \mathrm{kWh}$. Table 9 presents, a cash flow analysis of the solar power plant using Credit-Carbon bonus and the discount rate is equal to $7 \%$. The economic analysis of the plant leads to the determination of the following values: internal rate of return (IRR) 19.4\%, the net present value approximately equal to 667,869USD for an equal payback period 9.55 years. Table 10 presents a cash flow analysis of the CSP plant with 20\% loan and using Credit-Carbon bonus. In the economic analysis, it is found that IRR decreases by $3.6 \%$ compared to the value obtained from the preliminary analysis. Furthermore, the value of the NPV decreases to reach the value of 513797 USD and a payback period of 11.5 years as seen in Table 9. The value of IRR is closely related to the annual income of the plant and the initial investment. When the project is done without obtaining a loan from a financial institution, the IRR value is greater than $10 \%$ for the solar power plant project's bankability study. On the other hand, if the project is financed by a financial institution, the value of the IRR decreases considerably. The economic parameters such as present values, internal rate of return, and Payback-Period are calculated for different financing conditions using factors such as a loan, Credit-Carbon bonus and a discount rate. The gross profit margin is calculated by deducting the cost of goods sold from the revenue generated by the sale of the energy produced. The cash flows before interest and tax (EBIT) are calculated by deducting the operating cost from the gross profit and the cost related to grid connection and electricity transportation. After interest and tax (EAIT) are calculated by adding CER/Tax bonus (51.41 $\mathrm{USD} / \mathrm{MWh}$ ) and deducting loan payment from EBIT. 
Vol 3, Number 2, 2018

ISSN: 2548-0332 e-ISSN 2636-7904

doi: 10.23884/IJESG.2018.3.2.01

INESEG

Table 9. Annual cash flow analysis of the CSP plant without a loan

\begin{tabular}{|c|c|c|c|c|c|c|c|c|c|c|c|}
\hline Year & $\begin{array}{l}\text { Yearly prod. } \\
\text { (kWh) }\end{array}$ & $\begin{array}{c}\text { Surplus } \\
(\mathbf{k W h})\end{array}$ & Revenue (USD) & $\begin{array}{l}\text { Cost of good } \\
\text { sales (USD) }\end{array}$ & $\begin{array}{c}\text { The annual } \\
\text { saving of } \\
\text { manufacture } \\
\underline{\text { (USD) }}\end{array}$ & $\begin{array}{l}\text { Gross profit } \\
\text { (USD) }\end{array}$ & OPEX (USD) & EBIT (USD) & $\begin{array}{l}\text { CER/Tax } \\
\text { USD/MWh }\end{array}$ & EAIT (USD) & $\begin{array}{c}\text { C. Earning } \\
\text { (USD) }\end{array}$ \\
\hline 1 & 1671020 & 696020 & 92571 & 43849 & 202414 & 338834 & 27890 & 310944 & 81011 & 391954 & -3453828 \\
\hline 2 & 1671020 & 696020 & 92571 & 43849 & 212534 & 348954 & 27890 & 321064 & 85890 & 406955 & -3046873 \\
\hline 3 & 1671020 & 696020 & 92571 & 43849 & 213041 & 349460 & 27890 & 321570 & 85890 & 407461 & -2639412 \\
\hline 4 & 1671020 & 696020 & 92571 & 43849 & 213041 & 349460 & 27890 & 321570 & 85890 & 407461 & -2231951 \\
\hline 5 & 1671020 & 696020 & 92571 & 43849 & 213066 & 349486 & 30121 & 319365 & 85890 & 405255 & -1826696 \\
\hline 6 & 1659323 & 684323 & 91015 & 43112 & 215757 & 349885 & 30724 & 319161 & 85289 & 404450 & -1422246 \\
\hline 7 & 1647708 & 672708 & 89470 & 42381 & 218564 & 350414 & 31338 & 319076 & 84692 & 403768 & -1018478 \\
\hline 8 & 1636174 & 661174 & 87936 & 41654 & 221357 & 350947 & 33845 & 317102 & 84099 & 401201 & -617277 \\
\hline 9 & 1624720 & 649720 & 86413 & 40932 & 224131 & 351476 & 36553 & 314923 & 83511 & 398434 & -218843 \\
\hline 10 & 1613347 & 638347 & 84900 & 40216 & 226885 & 352001 & 39477 & 312524 & 82926 & 395450 & 176607 \\
\hline$r=7 \%$ & IRR $=19.4 \%$ & $\operatorname{PBP}(Y)=9.55$ & $N P V=667869 \$$ & & & & & & & & \\
\hline
\end{tabular}

Table 10. Revised assessment of annual cash flow analysis of the CSP plant with a loan (20\%) at 2.5\% after 3 years

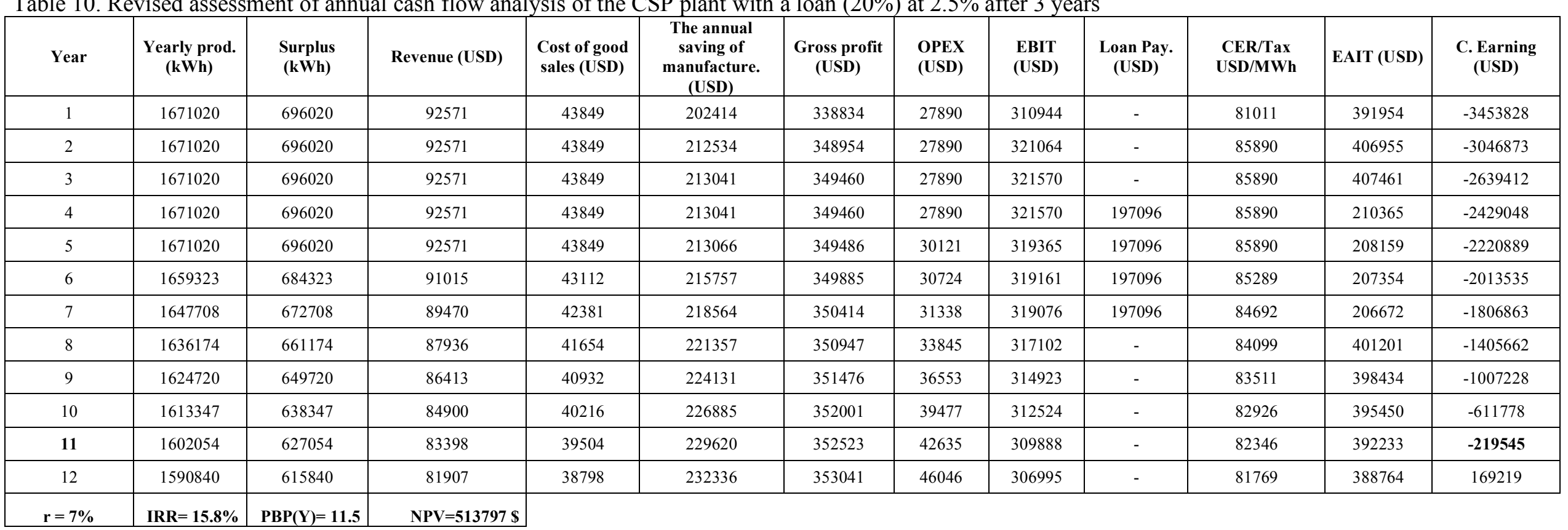




\subsection{Cost of Electricity}

For the financial analysis, an excel sheet was used to calculate the levelized cost of energy, initial capital cost per $\mathrm{kW}$, capacity factor, annual operating expenses (AOE) cost per $\mathrm{kW}$ and acceptable discount rate after tax. These results can be illustrated in Table 8 and Figure 2. The economic model assumes that the capacity factor of the solar power plant can't reach $21.7 \%$ according to the annual solar energy received on the site and the annual energy produced by the studied system. The study reveals that a slight variation of LCOE between the two simulated projects can be confronted using the variation of the maintenance and operating cost and the interest due to the loan from the bank. Annual cash flows are presented in Table 9-10.

Table 8: Overall performance and economic outputs of the solar power plant

\begin{tabular}{|c|c|c|c|}
\hline & Data & Unit & Izmir-1MWe \\
\hline \multirow{9}{*}{$\begin{array}{l}\text { Performance } \\
\text { metrics }\end{array}$} & Overall energy efficiency $(\eta)$ & - & $32.7 \%$ \\
\hline & Solar thermal power input & MWth & 3.12 \\
\hline & Annual operating hours & hours & 6810 \\
\hline & Annual generating energy production & GWh/year & 1.56 \\
\hline & Installed electricity capacity & MWe & 1.04 \\
\hline & Parasitic losses & kWe & 0.95 \\
\hline & Annual gross energy generated & GWh/year & 1.67 \\
\hline & Gross capacity & MW & 1.1 \\
\hline & Capacity Factor & $\mathrm{GWh} / \mathrm{GWh}_{\mathrm{e}}$ & 13.46 \\
\hline \multirow{8}{*}{$\begin{array}{c}\text { Financial } \\
\text { metrics }\end{array}$} & Annual water usage & $\mathrm{m}^{3}$ & 3533 \\
\hline & LCOE (nominal) & USDcents/kWh & 13.49 \\
\hline & LCOE (real) & USDcents/kWh & 19.3 \\
\hline & IRR & $\%$ & {$[19.4-15.8]$} \\
\hline & $\mathrm{r}$ & $\%$ & 7 \\
\hline & PBP & Years & [9.55- 11.55$]$ \\
\hline & NPV & USD & {$[667869-513797]$} \\
\hline & CER/TAX & $1 \mathrm{tCO}_{2}-7.2 \mathrm{USD}$ & $1 \mathrm{MWh}-7.14 \mathrm{tCO}_{2}$ \\
\hline
\end{tabular}

The average nominal and real LCOE are estimated to be equal to 193 USD/MWh and 135.1 USD/MWh respectively. Additionally, AOE, operating life per year and applicable values of discount rate are evaluated in Table 9. The calculated value of the cost per $\mathrm{kW}$ installed is less than 4000USD, this value is not related to other economic parameters. But the value of AOE depends on the annual production of electricity, the duration of intervention on the site and yearly fixed cost of O\&M. Generally, the value of the discount rate is $8 \%$ according to the literature. For this study, we have exceptionally used the value $7 \%$ as the value of the discount rate to cover the difficulties related to the bankability study. The amount and physical characteristic of Water, R134a and Therminol VP-1 used in the power block and the solar field respectively have a direct impact on the LCOE in such a way that the variables will lead to energy output and then lower LCOE. 


\begin{tabular}{|c|c|c|c|c|c|}
\hline \multirow[b]{2}{*}{ LCOE (USD/MWh) } & \multirow{2}{*}{\multicolumn{2}{|c|}{110}} & \multicolumn{3}{|c|}{ Baseline LCOE:135 USD } \\
\hline & & & 140 & & 175 \\
\hline ICC (USD/kW) & 2865.5 & & 3785 & 4245.3 & 5428.1 \\
\hline AOE (USD/MWh) & & & & 32 & 50 \\
\hline Capacity Factor & $22.6 \%$ & & $13.6 \%$ & $11.8 \%$ & \\
\hline Discount rate & & & $7 \%$ & $12 \%$ & \\
\hline Operating life -year & & 30 & & 20 & \\
\hline LCOE (USD/MWh) & & 110 & 140 & & 175 \\
\hline
\end{tabular}

Figure 2. Sensitivity analysis of LCOEs of the CSP plant

This value of the DNI has a non-desirable impact on the annual electricity production and LCOE. Several studies, like a research carried out by Abbas et al. [19] for an assessment of CSP using PTCs in the MENA region has conducted to obtain some specific data for the project bankability in the area. During this work, the authors carried out a value of the cost per $\mathrm{kW}$ installed, a real LCOE and a capacity factor which are between 5940 USD and 6320 USD per kW, 119.3 USD/MWh and 296USD/MWh and 44.2-21.1\% respectively. Moreover, the research done by Turchi et al. [20] showed that, the use of a heat storage system contributes significantly to the increase of the capacity factor and the LCOE through its high cost. Furthermore, the cost per $\mathrm{kW}$ installed of the studied project by the authors is above 4600USD with a capacity factor between $26 \%$ - 60\% and a LCOE between 179 USD/MWh and 99USD/MWh. In this terms it can be said that, the system studied in this work does not contain a storage system to supply electricity when sun rays aren't available. Due to the absence of the storage system in our study case, the capacity factor can't reach $22 \%$. On the other hand, this absence has conducted to obtain a low cost per $\mathrm{kW}$ installed (3725USD $/ \mathrm{kWh}$ ) and an acceptable LCOE (135USD/MWh). The IRENA's report shown that a suitable commercial power plant can be developed on the site with a direct normal irradiation between $2700 \mathrm{kWh} / \mathrm{m}^{2} /$ year and $2100 \mathrm{kWh} / \mathrm{m}^{2} /$ year [21].

\subsection{Sensitivity Analysis}

In this section, the sensitivity analysis both financial and performance outputs of the main system are considered. During this study, we also focused on the effects of the differences of configurations (\#1, \#2 and \#3) in order to predict optimization of the solar field. Calculated technical parameters of three different configurations are seen in Table 11. 
Table 11. Calculated technical parameters of the configurations

\begin{tabular}{|l|ccc|}
\hline Parameters & Configuration \#1 & Configuration \#2 & Configuration \#3 \\
\hline Net electiricty capacity $(\mathrm{kW})$ & 701 & 843.2 & 869 \\
Net exergy rate $(\mathrm{kW})$ & 687.3 & 840.3 & 864.9 \\
Estimated thermal production $\left(\mathrm{GWh}_{\mathrm{t}}\right)$ & 6.51 & 5.41 & 5.23 \\
Thermal production efficiency (\%) & 52.5 & 43.6 & 41.2 \\
Overall energy efficiencies (\%) & 24.94 & 30.01 & 30.9 \\
Overall exergy efficiencies (\%) & 24.4 & 29.9 & 30.7 \\
\hline
\end{tabular}

The improvement of solar field arrangement has a direct effect on annual energy production, initial capital cost per $\mathrm{kW}$, required cost for optimization (RCO) of the exergy destruction, energy loss and capacity factor. The previous research [10] showed that the energy output of the solar power plant depends on different input variables such as the mass flow rate of working fluid and HTF, the inlet and outlet temperature of steam water in a steam turbine. Therefore, the sensitivity analysis of the energy output variables is studied, in order to carry out a possibility to optimize solar field configuration \#1 and \#2 through required cost for optimization (RCO) as presented in Figure 3. The mass flow rate and physical properties of the heat transfer fluid are important data for a suitable heat transfer.

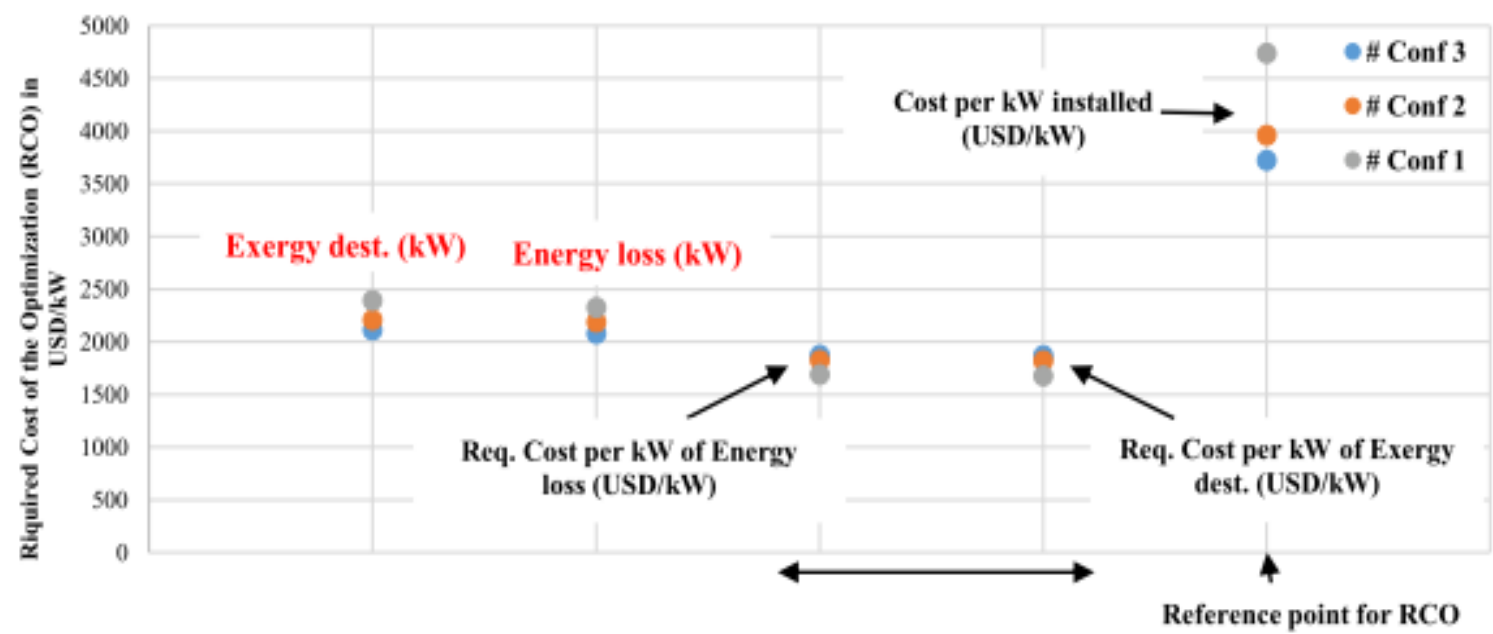

Figure 3. Required costs for plant optimization of $\mathrm{kW}$ of energy losses and exergy destruction and installed cost per $\mathrm{kW}$

The sensitivity analysis of solar field configuration leads to reduce energy losses and exergy destruction of the solar power plant. This analysis is characterized by required cost for optimization (RCO) of exergy destruction and energy losses. RCO should be less than the half of the estimated cost per $\mathrm{kW}$ installed (1863 USD/kW) in order to face economic considerations related to bankability of the project. Figure 3 show the RCO values in the configuration \#1 and \#2, for the energy loss, these values are 1690.2 and 1822.6 USD per $\mathrm{kW}_{\text {th }}$ respectively and for exergy destruction, these values are 1677 and 1820 USD per $\mathrm{kW}_{\mathrm{ex}}$ respectively. The analysis of solar field configuration \#3 showed that we need to spend more than 1873.4 USD to recover $1 \mathrm{~kW}_{\text {th }}$ of energy loss. This RCO value corresponds to the recovered thermal energy. If we need to generate electricity after recovering this energy, we have to consider other parameters such as conversion, transport and generation process with 
various losses of equipment used during these processes. For the conversion we have to remind that, the efficiency of solar power plant is $32.7 \%$. Then we are going to spend 5729.1 USD per $\mathrm{kWe}$ recovered in configuration \#3. This study reveals to us, the necessity of the exergoeconomic sensitivity before the construction of solar power plant. In order to determine a suitable solar field arrangement combined with the initial investment of the solar power plant, Figure 2-3 and Table 9-10 contribute to holding a final decision able to find a compromise between quality and managing total installation cost (TIC). From this figure, we can see that the solar field configuration\#3 does not need to be optimized due to a high cost of RCO per $\mathrm{kW}_{\text {th. }}$. But configuration\#1 which has a RCO of 5128.4 USD per $\mathrm{kWe}$ can be optimized.

\section{Conclusion}

An investigation for the techno-economic analysis of a small solar power plant with various solar field configurations on the same site has been done in this study in order to carry out plant optimization. For a $1 \mathrm{MWe}$ concentrated solar power, parabolic trough collector technology is chosen for the simulation in the case study. For the technical and economic parameters, SAM software, Meteonorm7 and an elaborated program on Microsoft Excel has been used conjointly for simulation and to find necessary values in the studied location. On the other hand, thermodynamic analysis is done by using Matlab software and an Excel datasheet is used to find out the financial values. The combined analysis in this study allows us to solve the current problem related to feasibility report and optimization of existing power plant using installed cost, O\&M cost and rehabilitation cost. The availability of DNI depends on the region where the study is taking place, then the importance of such kind of work has to be shown before any intervention in the solar field. The required cost for optimization (RCO) can be considered as one key data for any techno-economic analysis. Furthermore, discount rate, Credit Carbon bonus (CER/TAX), levelized cost of energy and internal rate of return are the main data of the bankability report. These results show that when the required cost for optimization (RCO) is higher than half of the cost per $\mathrm{kW}$ installed, the optimization work is still possible but might not be recovered soon during the plant exploitation. Then, the owners can consider a possibility to increase the plant capacity and technology used during the feasibility study. If the credit carbon bonus increases, CSP technologies could become a very successful area for independent power producers in Turkey since a payback period is closed to 11.5 years for $1 \mathrm{MWe}$ without taking into account the thermal energy generated. Furthermore, renewable energy policies in Turkey can increase the value of carbon credit (CER/TAX) for CSP in order to encourage independent power producers to invest more in solar energy by using CSP technologies. It is planned that comparison of different CSP technologies or consideration of these technologies installed in another region with higher DNI per year will be analyzed for future study.

\section{References}

[1] Behar O., Khellaf A., Mohammedi K., Ait-Kaci S., A review of integrated solar combined cycle system (ISCCS) with a parabolic trough technology, Renewable and Sustainable Energy Reviews, 39, pp. 223-250, 2014. 
[2] Ummadisingu A, Soni M.S., Concentrating solar power-technology, potential and policy in India, Renewable and Sustainable Energy Reviews, 15 (9), pp. 5169-5175, 2011.

[3] Fernández-García A., Zarza E., Valenzuela L., Pérez M., Parabolic-trough solar collectors and their applications, Renewable and Sustainable Energy Reviews, 14 (7), 1695-721, 2010.

[4] IEA, Technology Roadmap: Concentrating Solar Power, International Energy Agency - IEA, 2010. (Available from: https://www.iea.org/publications/freepublications/Publication/csp_ roadmap.pdf) [Accessed on January, 2019].

[5] Silva R., Berenguel M., Pérez M., Fernández-Garcia A., Thermo-economic design optimization of parabolic trough solar plants for industrial process heat applications with memetic algorithms, Applied Energy, 113, pp. 603-614. 2014.

[6] Mokheimer E.M.A, Dabwan Y.N., Habib M.A., Said S.A.M., Al-Sulaiman F.A., Technoeconomic performance analysis of parabolic trough collector in Dhahran, S.Arabia, Energy Conversion and Management, 86, pp. 622-633, 2014.

[7] Khalilpour R., Milani D., Qadir A., Chiesa M., Abbas A., A novel process for direct solvent regeneration via solar thermal energy for carbon capture, Renewable Energy, 104, pp. 60-75, 2017.

[8] Calise F., Denticed'Accadia M., Macaluso A., Piacentino A., Vanoli L., Exergetic and exergoeconomic analysis of a novel hybrid solar-geothermal polygeneration system producing energy and water, Energy Conversion and Management, 1, pp. 200-220, 2016.

[9] Zare V. and Hasanzadeh M., Energy and exergy analysis of a closed Brayton cycle-based combined cycle for solar power tower plants. Energy Conversion and Management, 128, pp. $227-$ $237,2016$.

[10] Biboum A.C., Mwanza M., Yilanci A., Performances analysis of combined Rankine and absorption refrigeration cycles for a small size solar power plant, IEA SHC International Conference on Solar Heating and Cooling for Buildings and Industry, ISES Solar World Congress, Abu Dhabi, 2017.

[11] Adibhatla S. and Kaushik S.C., Exergy and thermoeconomic analyses of $500 \mathrm{MWe}$ sub-critical thermal power plant with solar aided feed water heating, Applied Thermal Engineering, 123, pp. 340-352, 2017.

[12] Ahmadzadeh A., Salimpour M.R., Sedaghat A., Thermal and exergoeconomic analysis of a novel solar driven combined power and ejector refrigeration (CPER) system, International Journal of Refrigeration, 83, pp. 143-156, 2017.

[13] Bishoyi D. and Sudhakar K., Modeling and performance simulation of 100 MW LFR based solar thermal power plant in Udaipur India, Resource-Efficient Technologies, 3(4), pp. 365-377, 2017. 
[14] Bonyadi N., Johnson E., Baker D., Techno-economic and exergy analysis of a solar-geothermal hybrid electric power plant using a novel combined cycle, Energy Conversion and Management, 156, pp. 542-554, 2018.

[15] Meteonorm, Typical Meteorological Years, TMY-3, 2019. (Available from: https://meteonorm.com/typical-meteorological-years

[16] System Advisor Model (SAM), NREL, 2019. (Available from: https://sam.nrel.gov/download)

[17] Shahin M.S., Orhan M.F., Uygul F., Thermodynamic analysis of parabolic trough and heliostat field solar collectors integrated with a Rankine cycle for cogeneration of electricity and heat, Solar Energy, 136, pp. 183-196, 2016.

[18] Petela R., Exergy of undiluted thermal radiation, Solar Energy, 74, pp. 469-488, 2003.

[19] Abbas M., Belgroun Z., Aburidah H., Merzouk N.K., Assessment of a solar parabolic trough power plant for electricity generation under Mediterranean and arid climate conditions in Algeria, Energy Procedia, 42, pp. 93-102, 2013.

[20] Turchi C., Mehos M., Ho C., Kolb G.J., Current and Future Costs for Parabolic Trough and Power Tower Systems in the US Market, NREL/CP 5500-49303, 2010. (Available from: https://www.nrel.gov/docs/fy11osti/49303.pdf) [Accessed on January, 2019].

[21] IRENA, Renewable Power Generation Costs in 2012: An Overview, International Renewable Energy Agency, IRENA Report, 2013. (Available from: https://www.irena.org/-/media/Files/ IRENA/Agency/Publication/2013/Overview_Renewable-Power-Generation-Costs-in-012.pdf) [Accessed on January, 2019]. 